\title{
Increase in AP-1 Transcription Factor DNA Binding Activity by Valproic Acid
}

Guang Chen, M.D., Peixiong Yuan, M.D., Ph.D., David B. Hawver, Ph.D., William Z. Potter, M.D., Ph.D., and Husseini K. Manji, M.D., F.R.C.P.C.

Valproic acid (VPA), a simple branched fatty acid anticonvulsant, has been demonstrated to have clinical efficacy in the treatment of manic-depressive illness (Bowden et al., 1994), but the mechanism (s) by which VPA produces its therapeutic effects remain to be elucidated. $V P A^{\prime}$ 's clinical antimanic action require a lag period for onset and are not immediately reversed upon discontinuation of treatment, effects that suggest alterations at the genomic level; we therefore investigated the effects of VPA on the modulation of the DNA binding activity of key transcription factors. DNA binding activities of activator protein $1(A P-1)$ and $C A M P$ responsive element binding protein (CREB) were studied in acute (hours) and chronic (days) VPA-treated rat C6 glioma cells. VPA did not affect CREB DNA binding activity, but concentrationand time-dependently increased AP-1 DNA binding

KEY WORDS: Valproic acid; Transcription factors; AP-1; CREB; $c$-fos; c-jun; Mania; Depression; Lithium; Anticonvulsant; Bipolar Affective Disorder

From the Molecular Pathophysiology Program (GC, PY, HKM), Schizophrenia and Mood Disorders Clinical Research Division, Department of Psychiatry and Behavioral Neurosciences, Wayne State University School of Medicine, Detroit, MI; the Neuropsychiatric Research Unit (HKM), Detroit Receiving Hospital, Detroit, MI; and the Section on Clinical Pharmacology (DBH, WZP), National Institute of Mental Health, Bethesda, MD.

Address correspondence to: Husseini K. Manji, M.D., Director, Schizophrenia and Mood Disorders Clinical Research Division, Department of Psychiatry and Behavioral Neurosciences, Wayne State University School of Medicine, UHC 9B, 4201 St. Antoine Boulevard, Detroit, MI 48201.

Received May 1, 1996; revised September 7, 1996; accepted September 11,1996 activity. The activity was raised at 2 hours (the shortest time examined) and remained high after 6 days (the longest time used) of continuing VPA treatment. VPA also enhanced AP-1 DNA binding activity in human neuroblastoma (SH-SY5Y) cells. Because the effects of VPA were markedly inhibited by cycloheximide, they appear to require new protein synthesis. Taken together, the data suggest that antimanic agents may affect gene expression by modulation of the activity of major transcription factors; in view of the key roles of these nuclear transcription regulatory factors in long-term neuronal plasticity and cellular responsiveness, these effects may play a major role in VPA's therapeutic efficacy and are worthy of further study. (C) 1997 American College of Neuropsychopharmacology [Neuropsychopharmacology 16:238-245, 1997]

Valproic acid (VPA), a simple branched fatty acid anticonvulsant, has been demonstrated to have clinical efficacy in the treatment of manic-depressive illness (Bourgeois 1989; Bowden et al. 1994). Although the anticonvulsant effects of VPA can be observed quite rapidly, its therapeutic effects in the treatment of manic-depressive illness generally requires chronic administration with a lag time of onset of action of several days to weeks. The anticonvulsant effects of VPA have been postulated to involve its biochemical actions on voltage-dependent $\mathrm{Na}^{+}$channels and/or inhibitory and excitatory amino acid systems (Rogawski and Porter 1990; Löscher 1993). The mechanism by which VPA produces its therapeutic effects in the treatment of manic-depressive illness remains to be elucidated, but has been postulated to involve biochemical effects ob- 
served after chronic, but not acute, administration (Post et al. 1992) and possibly alterations in gene expression.

We have recently demonstrated that long-term exposure of rat C6 glioma cells to concentrations of VPA similar to those used therapeutically produces a significant decrease in total protein kinase $\mathrm{C}$ (PKC) activity, accompanied by isozyme selective decreases in PKC $\alpha$ and $\epsilon$ (Chen et al. 1994a). Chronic VPA exposure also decreased the levels of a major PKC substrate myristoylated alanine rich $C$ kinase substrate, (MARCKS) but increased its phosphorylation state (Chen et al. 1994b). Although the precise mechanisms underlying these biochemical changes remain to be fully elucidated, it is noteworthy that prolonged PKC activation is known to produce a decrease in the levels of PKC isozymes, as well as in the levels of MARCKS and MARCKS mRNA (Manji and Lenox 1994; Manji et al. 1995). Together, these results suggest that VPA may bring about an early activation of PKC, thereby initiating a cascade of effects that may be ultimately responsible for its longterm therapeutic effects. In this context, it is noteworthy that biochemical changes requiring such prolonged administration of drug have been postulated to involve alterations at the genomic level (Manji and Lenox 1994).

Activator protein-1 (AP-1) and cyclic AMP response element binding protein (CREB) are two families of transcription factors that bind to unique DNA consensus sequences in the regulatory domain of genes. These transcription factors are abundantly expressed in neuronal cells (Sheng and Greenberg 1990). Multiple intracellular signal transduction pathways control the DNA binding activities of AP-1 and CREB. The protein kinases such as protein kinase $C$ (PKC), protein kinase $A(P K C)$ and tyrosine kinases (TK) as well as the protein phosphatases are all involved in the activation and inactivation of these transcription factors (Jackson 1992; Karin and Smeal 1992). Because AP-1 and CREB are known to modulate the expression of key proteins involved in neuronal excitability, including receptors, neuropeptides, and key enzymes in neurotransmitter biosynthesis, it is possible that mood-stabilizing agents bring about their complex effects on neuronal function through alterations in the activities of these key transcription factors. To test this hypothesis, we investigated the effects of chronic administration of VPA on the DNA-binding activities of AP-1 and CREB in cultured neuronal and glioma cells.

\section{METHODS AND MATERIALS}

Rat C6 glioma cells and human neuroblastoma SH-SY5Y cells were cultured in a humidified atmosphere of $95 \%$ air and $5 \% \mathrm{CO}_{2}$ at $37^{\circ} \mathrm{C}$. Dublecco's modified Eagle's medium plus $5 \%$ fetal bovine serum and Minimum Essential Medium plus $10 \%$ fetal bovine serum were used for C6 and SY5Y cell cultures, respectively. Both media also were supplied with $100-\mathrm{IU} / \mathrm{ml}$ penicillin and 50 $\mu \mathrm{g} / \mathrm{ml}$ streptomycin. The medium was changed every 3 to 4 days. VPA (RBI, Natick, MA) was directly dissolved in the medium to attain final concentrations of $0.25,0.5$, or $1.0 \mathrm{mM}$. The cells were exposed to VPA for varying periods of time from 2 hours to 7 days. To investigate the mechanism(s) underlying any putative effects of VPA on transcription factor activity, cycloheximide $(20 \mu \mathrm{g} /$ $\mathrm{ml})$ and Bisindolylmaleimide $(3 \mu \mathrm{M})$ were used. Cycloheximide (which inhibited $97 \%$ of ${ }^{35} \mathrm{~S}$-methionine incorporation into $\mathrm{C} 6$ cells, data not shown) and Bisindolylmalemide were added into the cell culture medium 1 hour prior to the addition of VPA in the experiments designed to study the effects of inhibitors of protein synthesis and PKC on DNA-binding activities of transcription factors. Cells were washed with $10 \mathrm{ml}$ phosphate-buffered saline three times prior to whole-cell extract preparation.

DNA-binding assays were conducted as described by Korhausesr and associates (Korhauser et al. 1992) with some modifications. The consensus oligos (AP-1:5'CGC TTG ATG ACT CAG CCG GAA-3'; CREB: 5'-AGA GAT TGC CTG ACG TCA GAG AGC TAG-3') purchased from Santa Cruz Biotechnology Inc. (Santa Cruz, CA) were labeled with $\left[\gamma^{3}{ }^{32} \mathrm{P}\right]$ ATP (Amersham, Arlington Heights, IL) using T4 kinase according to the manufacturers specifications (GIBCO BRL, Gaithersburg, MD). Free $\left[\gamma^{-32} \mathrm{P}\right]$ ATP was separated from labeled oligos using a pushing column from Stratagene (La Jolla, CA). The washed cells were lysed in the extraction buffer containing $20 \mathrm{mM}$ Hepes ( $\mathrm{pH} 7.8$ ), $125 \mathrm{mM} \mathrm{NaCl}, 5 \mathrm{mM}$ $\mathrm{MgCl}_{2}, 0.2 \mathrm{mM}$ EDTA, $0.2 \mathrm{mM} \mathrm{Na} \mathrm{VO}_{4}, 5 \mathrm{mM}$ DTT, 0.2 $\mathrm{mM}$ PMSF, $10 \mu \mathrm{g} / \mathrm{ml}$ Leupeptin, $10 \mu \mathrm{g} / \mathrm{ml}$ Aprotinin, $12 \%$ glycerol, and $0.1 \%$ NP- 40 . The lysates were sonicated for $10 \mathrm{~s}$ and then centrifuged at $14,000 \times \mathrm{g}$ for 15 minutes to remove residual debris. The whole-cell extracts ( $9 \mu \mathrm{g}$ protein) were incubated with 35 fmoles of ${ }^{32} \mathrm{P}$-labeled oligos in the reaction buffer containing 10 mM Hepes ( $\mathrm{pH} 7,8), 1 \mathrm{mM}$ spermidine, $3 \mathrm{mM} \mathrm{MgCl}_{2}, 3$ $\mathrm{mM} \mathrm{DTT}, 7.2 \%$ glycerol, $0.06 \% \mathrm{NP}-40$ and $0.15 \mu \mathrm{g} / \mu \mathrm{l}$ poly dI:dC at $37^{\circ} \mathrm{C}$ for 15 minutes. The DNA-binding reaction was terminated by the addition of $5 \times$ loading buffer containing $267.5 \mathrm{mM}$ Tris, $266.8 \mathrm{mM}$ boric acid, $4.8 \mathrm{mM}$ EDTA, $3.2 \%$ glycerol, $0.03 \%$ bromophenolbur, and $0.03 \%$ xylene cyanol. The reaction mixtures were then subjected to gel electrophoresis using a $6 \%$ DNA retardation gel, run in TBE buffer at $100 \mathrm{~V}$ for about 1 hour. Following electrophoresis, the gel was dried and exposed to X-ray film. The autoradiogram of the gel was scanned using an image analysis system using NIH image 1.55 computer software.

The specificity of the DNA-binding assay was verified by both competition and supershift experiments. In the competition experiments, a 50-fold excess of unlabeled oligos or mutant oligos (AP-1: 5'-CGC TTG ATG 
ACT TGG CCG GAA-3'; CREB: 5'-AGA GAT TGC CTG TGG TCA GAG AGC TAG-3'; both from Santa Cruz Biotechnology Inc., Santa Cruz, CA) were included in the binding mixture. In the supershift experiment, the binding incubations were extended for another $15 \mathrm{~min}$ utes and were conducted with the addition of $1 \mu \mathrm{l}$ of an antibody against the fos family ( $s c-413 x$, Santa Cruz Biotechnology, Santa Cruz, CA), an antibody against the jun family (sc-44x, Santa Cruz Biotechnology, Santa Cruz, CA), or an antibody against CREB (Upstate Biotechnology, Lake Placid, NY).

Protein phosphatase activity assays were carried out using the method of Cohen (Cohen et al. 1988). In brief, washed $\mathrm{C} 6$ cells were lysed by polytron homogenization in a buffer containing $50 \mathrm{mM}$ Tris- $\mathrm{HCl}(\mathrm{pH} 7.5), 0.1$ $\mathrm{mM}$ EDTA, $0.1 \mathrm{mM}$ EGTA, $0.1 \% \beta$-mercaptoethanol, $0.5 \%$ Triton X-100, $25 \mu / \mathrm{ml}$ leupeptin, and $25 \mu / \mathrm{ml}$ aprotinin. The cell lysates were centrifuged at $300 \times \mathrm{g}$ for 15 minutes to remove cell debris. An aliquot of wholecell extracts $(1 \mu \mathrm{g}$ protein) was then incubated with ${ }^{32}$ P-labeled phosphorylase A (a substrate for protein phosphatases 1 and $2 \mathrm{~A}$ ) at $30^{\circ} \mathrm{C}$ for 10 minutes in the presence of varying concentrations of VPA or okadaic acid (a known protein phosphatase inhibitor). The incubation was terminated by the addition of $20 \%$ TCA and ${ }^{32} \mathrm{P}$ released from phosphorylase A was measured using a scintillation counter. The $\mathrm{IC}_{50}$ values were computed using NIH ALLFIT software.

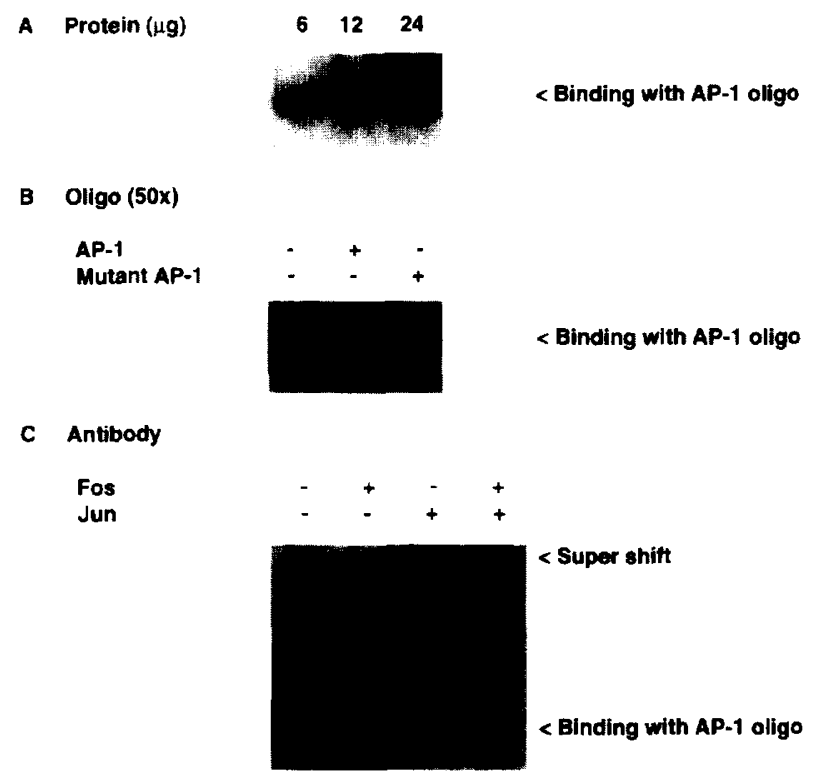

Figure 1. ${ }^{32} \mathrm{P}$-labeled AP-1 oligo binding in whole rat C6 glioma cell extracts was conducted as described in Methods and Materials. (A) Binding assays carried out in the presence of varying amount of protein as indicated in the figure. (B) Binding assays conducted in the presence of 50 -fold excesses of either AP-1 oligo or mutant AP-1 oligo. (C) Binding assays conducted in the presence of antibodies against fos and jun families, as indicated in the figure.

\section{RESULTS}

\section{Specificity and Dose-Response Characteristics of AP-1 and CREB Consensus Oligos}

Incubation of whole C6 cell extracts with ${ }^{32} \mathrm{P}$-labeled consensus oligos for either AP-1 or CREB resulted in binding that was linear with respect to the amount of total protein in the extracts ranging from 0 to $24 \mu \mathrm{g} /$ tube (Figures $1 \mathrm{~A}$ and $2 \mathrm{~A}$ ). The addition of 50 -fold excess of unlabeled AP-1 or CREB consensus oligos completely eliminated the binding of the respective ${ }^{32} \mathrm{P}$-labeled consensus oligos for either AP-1 or CREB; however, incubation with 50-fold excess of mutant oligos was completely without effect (Figures 1B and 2B). Addition of an antibody directed against the jun family, or the addition of antibodies against the fos and jun families resulted in the expected upward shift of the band representing AP-1 binding (Figure 1C). Similarly, the addition of an antibody against CREB resulted in the expected upward shift of the band representing CRE binding (Figure 2C). These data indicated that the DNA binding assay was specific.

\section{Effects of VPA Exposure on AP-1 and CREB DNA-Binding Activity}

Exposure of rat C6 glioma cells to $1 \mathrm{mM}$ of VPA for 2 to 16 hours resulted in a gradual increase in the DNA-binding activity of AP-1, resulting in an approximate doubling of the AP-1 DNA-binding activity at 16 hours (Figure

A Protein $(\mu \mathrm{g})$

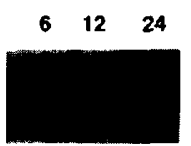

< Binding with CRE oligo

B Oligo (50x)
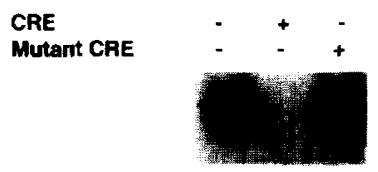

< Binding with CRE oligo

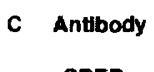

CREB
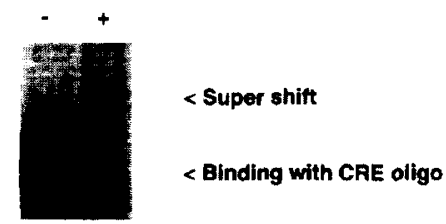

Figure 2. ${ }^{32} \mathrm{P}$-labeled CRE oligo binding in whole rat $\mathrm{C} 6$ glioma cell extracts was conducted as described in Methods and Materials. (A) Binding assays carried out in the presence of varied amount of protein as indicated in the figure. (B) Binding assays conducted in presence of 50 -fold excesses of either CRE oligo or mutant CRE oligo. (C) Binding assays were conducted in the presence of antibody against CREB. 

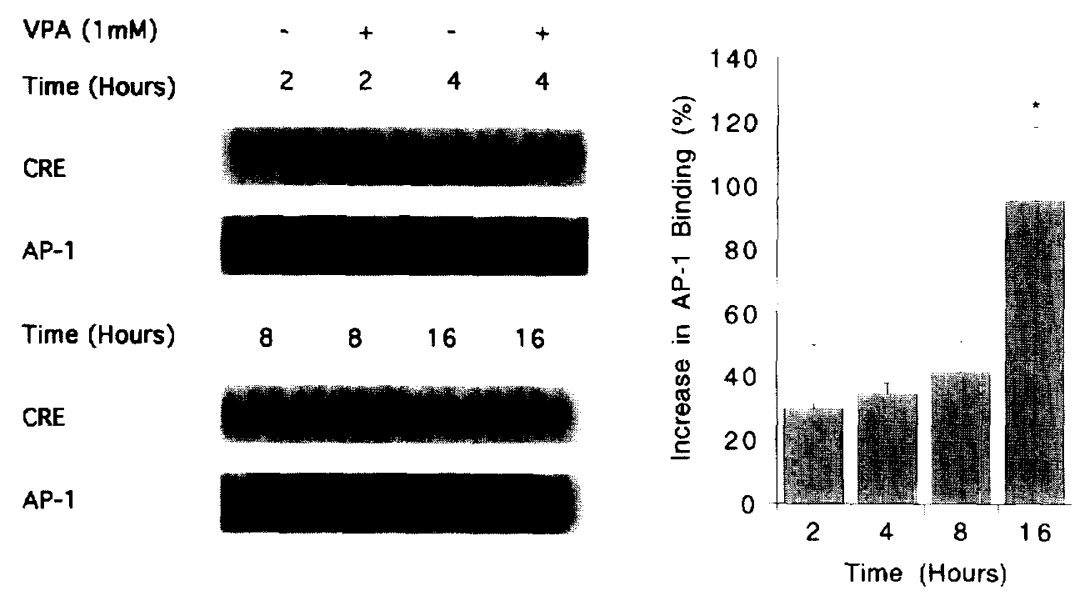

Figure 3. Rat C6 glioma cells were exposed to $1 \mathrm{mM}$ VPA for varying periods of time as indicated in the figure. The whole cell extracts and DNA binding assays were conducted as described in Methods and Materials. The autoradiogram of the gels were scanned using an image system and analyzed using $\mathrm{NIH}$ image 1.55 computer software. Values are mean \pm SE from three or four experiments in arbitrary units. ${ }^{*} p<.05$.

3). By contrast, exposure of C6 glioma cells to VPA (1 $\mathrm{mM}$ ) did not have any significant effects on the DNAbinding activity of CREB at any time (Figure 3). Addition of 0.1 or $1 \mathrm{mM}$ of VPA to the reaction mixture did not alter the DNA-binding activity of AP-1. At higher concentrations $(10 \mathrm{mM})$, addition of VPA to the reaction mixture reduced the DNA-binding activities for AP-1 (Figure 4). Exposure of human SK-SY5Y neuroblastoma cells to $1 \mathrm{mM}$ of VPA for 24 hours resulted in a significant (near double) increase in the DNA-binding activities of AP-1 in the whole-cell extracts (Figure 5).

\section{Effects of VPA Exposure on AP-1 DNA-Binding Activity: Concentration and Time Dependence}

Exposure of rat C6 glioma cells to varying concentrations of VPA (from 0.25 to $2 \mathrm{mM}$ ) for 12 hours resulted in a gradual increase in DNA-binding activity of AP-1 (Figure 6); the increases in DNA-binding activity after exposure to $0.5,1.0$, or $2.0 \mathrm{mM}$ VPA all reached statistical significance. Exposure of these cells to 0.25 to $1 \mathrm{mM}$ VPA for one day also resulted in gradual increases in the DNA-binding activity of AP-1, reaching $200 \%$ of baseline (Figure 7). Similar results also were observed after 3 to 6 days of VPA exposure (Figure 7). The $\mathrm{EC}_{50}$ values for the increase in AP-1 DNA-binding activity by VPA could not be calculated because the increases in DNA-binding activities did not plateau with the highest concentrations of VPA used (at any time exposure). It was not possible to use higher concentrations of VPA or longer exposure times, because these resulted in the detaching of cells.

\section{Effects of Inhibition of Protein Synthesis, Protein Kinases and Protein Phosphatases on the VPA- Induced Increases in AP-1 DNA-Binding Activity}

Incubation of $\mathrm{C} 6$ cells with the protein synthesis inhibitor cycloheximide for 13 hours modestly decreased DNA-binding activities of AP-1 (Figure 8A), but completely blocked the VPA $(1 \mathrm{mM})$-induced increase in AP-1 DNA-binding activity. Incubation of C 6 cells with the PKC inhibitor bisindolymaleimide (Figure $8 \mathrm{~B}$ ) for

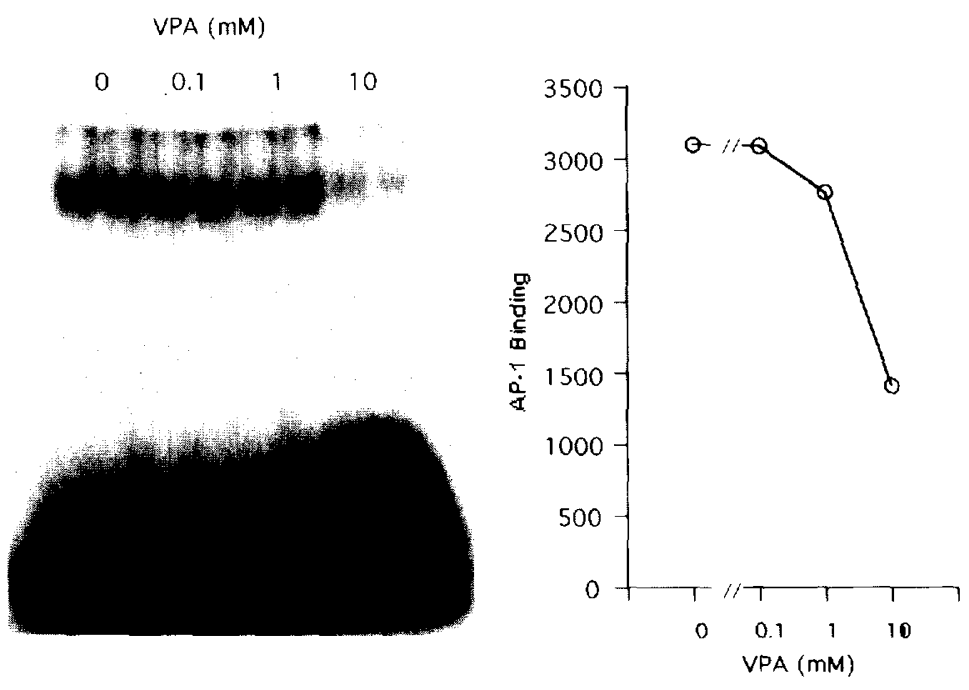

Figure 4. The AP-1 DNA binding assay was performed as described in Methods and Materials using whole C6 cell extracts. VPA was added in the reaction mixture to the concentration indicated in the figure. The autoradiograms of the gels were scanned using an image system and analyzed using $\mathrm{NIH}$ image 1.55 computer software. Similar results were also obtained from an additional experiment. 


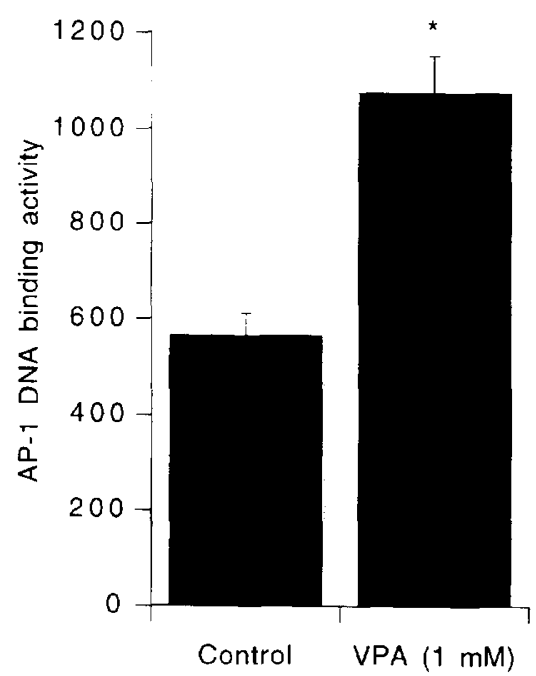

Figure 5. Human SK-SY5Y cells were cultured and exposed to $1 \mathrm{mM}$ VPA for 1 day as described in Methods and Materials. The whole-cell extract and AP-1 DNA binding assay were conducted as described. The autoradiograms of the gels were scanned using an image system and analyzed using NIH image 1.55 computer software. Values are mean $\pm \mathrm{SE}$ from three or four experiments in arbitrary units. ${ }^{*} p<.03$ compared to control.

13 hours modestly decreased the DNA-binding activity of AP-1 (Figure 8B) and attenuated (but did not eliminate) the VPA (1 mM)-induced increase in AP-1 DNAbinding activity (Figure $8 \mathrm{~B}$ ).

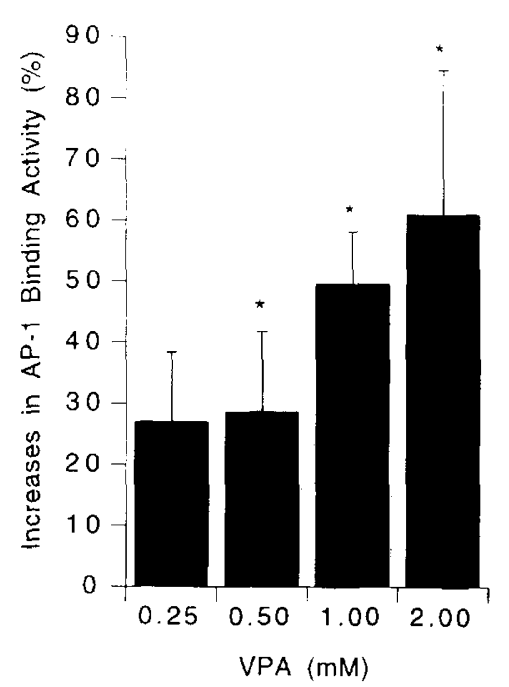

Figure 6. Rat C6 glioma cells were exposed to VPA for 12 hours at the concentrations indicated in the figure. The whole-cell extracts and DNA binding assay were conducted as described. The autoradiogram of the gels were scanned using an image system and analyzed using NIH image 1.55 computer software. Values are mean \pm SE from 3 or 4 experiments in arbitrary units. ${ }^{*} p<.05$ compared to control (paired $t$-test).
We next investigated whether VPA was exerting its effects via inhibition of protein phosphatases. As expected, okadaic acid concentration-dependently inhibited protein phosphatase activity with an $\mathrm{IC}_{50}$ of approximately $6 \mathrm{nM}$ (5.3-6.6 nM) (Figure 9). By contrast, VPA was completely without effect on protein phosphatase activity (Figure 9).

\section{DISCUSSION}

In the present study, we have demonstrated that the anticonvulsant and antimanic agent VPA selectively enhances the DNA-binding activity of AP-1 in cultured rat glioma and human neuroblastoma cells. These effects are observed at concentrations of VPA similar to those attained in the plasma in the clinical treatment of neuropsychiatric disorders (McElroy et al. 1992). VPA at these concentrations was not toxic to the cells, similar to what we have previously observed (Chen et al. 1994a, 1994b). These effects of VPA are both concentration- and time-dependent.

To further characterize the mechanism(s) by which VPA enhances the DNA-binding activity of AP-1, we conducted an additional series of experiments. VPA added to the incubation mixture was without effect on AP-1 DNA-binding activity, suggesting that VPA exerts its effects on AP-1 DNA-binding activity indirectly. It is now well established that PKC plays a vital role in transcriptional and posttranscriptional regulation of AP-1 activity (Jackson et al. 1992; Karin et al. 1992; Woodgett et al. 1993). In view of the previously described effects of VPA on PKC isozymes, we next investigated the effects of a selective PKC inhibitor. As expected, exposure of rat $\mathrm{C} 6$ glioma cells to the PKC inhibitor bisindolylmaleimide alone reduced AP-1 DNA-binding activity; however, coincubation of the PKC inhibitor with VPA only attenuated (but did not eliminate) the VPA-induced increase in AP-1 DNA-binding activity. Thus, at this point, the precise role of PKC isozymes in mediating VPA's effects on AP-1 remains to be fully elucidated.

It has been reported that dephosphorylation of the regulatory site in the DNA-binding domain increases the DNA-binding activity of c-jun (Woodgett et al. 1993). To investigate the possible role of protein phosphatases in mediating VPA's effects on AP-1 activity, the effects of VPA on protein phosphatase activity were determined in parallel with those of a well-known protein phosphatase inhibitor okadaic acid. Okadaic acid concentration-dependently inhibited the release of ${ }^{32} \mathrm{P}$ from labeled substrates with an $\mathrm{IC}_{50}$ of approximately $6 \mathrm{nM}$, a value similar to the reported $\mathrm{IC}_{50}$ of inhibition of protein phosphatase 1 (PP1) (Cohen et al. 1989). VPA, at therapeutically relevant concentrations, did not alter the release of ${ }^{32} \mathrm{P}$ from the labeled substrates, suggesting that VPA is completely without effect on the activity of these protein phosphatases. 


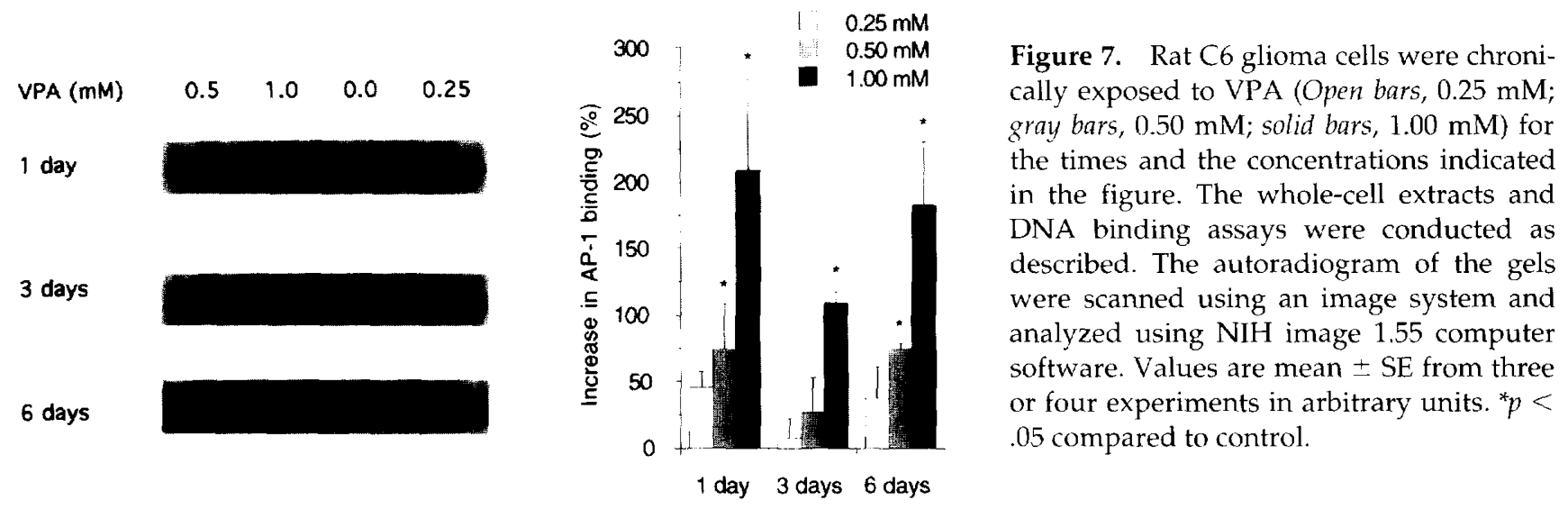

To investigate the possible involvement of new protein synthesis in VPA's effects on AP-1 DNA-binding activity, cycloheximide was used. Incubation of cells with cycloheximide alone produced a modest reduction in AP-1 DNA-binding activity. In contrast to the effects observed with the PKC inhibitor, cycloheximide markedly attenuated VPA's effects. These results suggest that VPA indirectly increases AP-1 DNA-binding activity by a mechanism that appears to involve new protein synthesis; the precise mechanism underlying these complex effects remains to be fully elucidated.

It has been reported that VPA enhances the expression of genes coded by the human cytomegalovirus (HCMV) and by the human immunodeficiency virus (HIV) (Simon et al. 1994; Kuntz-Simon et al. 1995) in infected cultured cells. The studies also have demonstrated that VPA increases expression of the reporter gene ( $\beta$-galactosidase) driven by HCMV promoter/enhancer or HIV long-terminal repeat (HIV/LTR). Be- cause the regulatory domains of HCMV and HIV both contain AP-1 elements, the effects of VPA on the viral gene expression may be related to its effects on AP-1.

At present, the therapeutic relevance of the effects of VPA on AP-1 DNA-binding activity is unclear. As discussed in the Introduction, however, the antimanic effects of VPA require a lag period for onset and are not immediately reversed upon discontinuation of treatment, effects that suggest alterations at the genomic level. In this context, it is especially noteworthy that the prototypical antimanic agent lithium has been demonstrated to have potentially very similar effects on AP-1. Thus, in PC12 cells, lithium potentiates muscarinic M1 receptor-induced accumulation of c-fos mRNA (Kalasapudi et al. 1990) and forskolin or dexamethasone induced AP-1 DNA-binding activity and c-jun, c-fos, and fra-1 gene expression (Bullock et al. 1994). In rats, lithium administration enhances muscarinic M1-induced increases in c-fos, jun-B, c-jun, and jun-D mRNAs in the
A

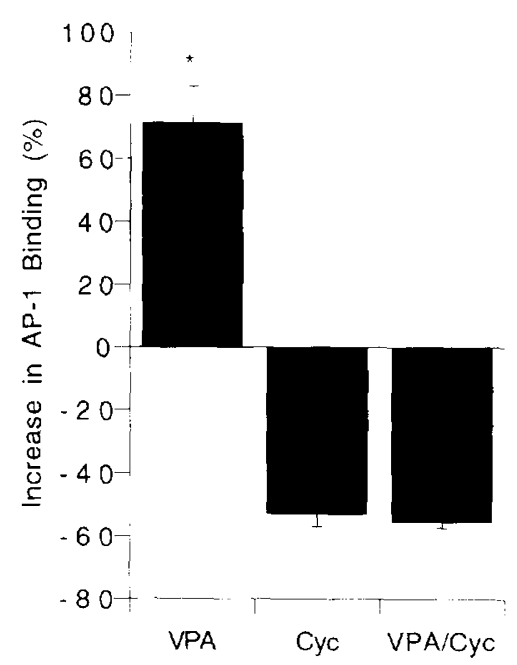

B

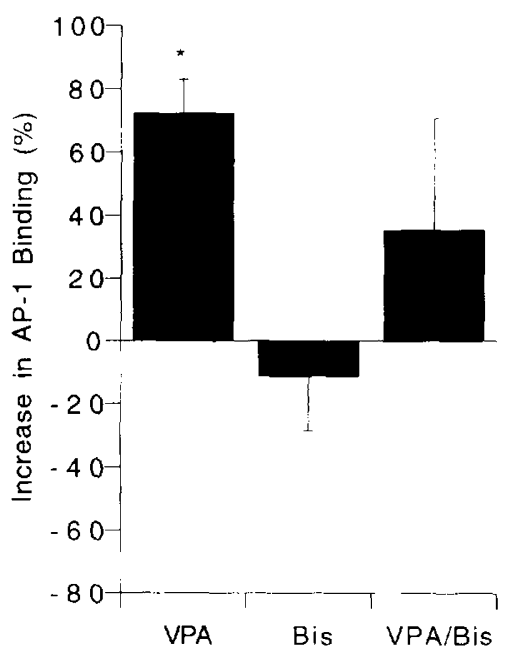

Figure 8. Cultured rat C6 glioma cells were coexposed to $1 \mathrm{mM} \mathrm{VPA}$ and $20 \mathrm{mg} /$ $\mathrm{ml}$ of protein synthesis inhibitor cycloheximide (A) or $3 \mu \mathrm{M}$ PKC inhibitor bisindolylmaleimide (B) for 13 hours. The inhibitors were 1 hour prior to VPA. The whole-cell extracts and AP-1 DNA binding assays were conducted as described. Values are mean \pm SE from three or four experiments. ${ }^{*} p<.01$ compared to control. 


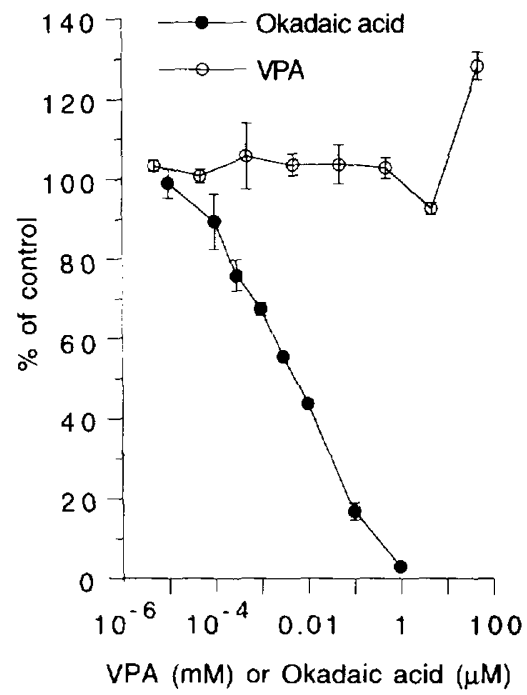

Figure 9. The C6 extracts were prepared as described in Methods and Materials. An aliquot of whole-cell extracts (1 $\mu \mathrm{g}$ protein) was then incubated with ${ }^{32} \mathrm{P}$-labeled phosphorylase a (substrate) at $30^{\circ} \mathrm{C}$ for 10 minutes in the presence of different concentrations of VPA (open circles) or okadaic acid (solid circles) as indicated in the figure. The incubation was terminated by adding $20 \%$ TCA, and ${ }^{32} \mathrm{P}$ released from phosphorylase was measured using a scintillation counter. The fractions of ${ }^{32} \mathrm{P}$ release at different concentration of drugs were calculated based on control ( 0 concentration). Values are mean $\pm S E$ from three or more different experiments.

cerebral cortex and hippocampus (Weiner et al. 1991; Williams and Jope 1994), and serotonin $5-\mathrm{HT}_{2}$ induced increase in c-fos immunoreactivity in the cerebral cortex (Leslie et al. 1993). Although the enhancement of AP-1 DNA-binding activity by VPA observed in the present study is in the same direction as lithium's action both in vivo and in vitro, it is noteworthy that VPA produces these effects in isolation, whereas lithium's effects are primarily to potentiate the responses to other agents; those observations suggest that different mechanisms are operative for each agent. In any case, whatever the underlying mechanism(s), it is striking that these two clinically effective, but structurally dissimilar antimanic agents bring about similar effects on AP-1 DNA-binding activity.

In conclusion, we have demonstrated that VPA, at therapeutically relevant concentrations, increases AP-1 DNA-binding activity in cultured cells by a mechanism that appears to involve new protein synthesis. In preliminary experiments, we also have found increased AP-1binding activity in the rat cerebral cortex and hippocampus after 7 days of VPA administration. In view of the key roles of these nuclear transcription regulatory factors in long-term neuronal plasticity and cellular responsiveness, these effects may play a major role in VPA's therapeutic efficacy and are worthy of further study.

\section{ACKNOWLEDGMENTS}

The authors wish to thank Ms. Celia Knobelsdorf for outstanding editorial assistance.

\section{REFERENCES}

Bourgeois BFD (1989): Valproate: Clinical Use. In Levy R, Mattson R, Meldrum B, Penry JK, Dreifuss FE (eds), Antiepileptic, ed 3, New York, Raven, pp 633-641

Bowden CL, Brugger AM, Swenn AA, Calabrese JR, Janicak PG, Petty F, Dilsaver SC, Davis JM, Rush AJ, Small JG (1994): Efficacy of divalproex vs lithium and placebo in the treatment of mania. JAMA 271:918-924

Bullock BP, McNeil GP, Dobner PR (1994): Synergistic induction of neurotensin gene transcription in PC 12 cells parallels changes in AP-1 activity. Brain Res Mol Brain Res 27:232-242

Chen G, Manji HK, Hawver DB, Wright CB, Potter WZ (1994a): Chronic sodium valproate selectively decreases protein kinase $C$ alpha and epsilon in vitro. J Neurochem 63:2361-2364

Chen G, Manji HK, Hawver DB, Potter WZ (1994b) Selective decreases of PKC isozymes and PKC substrates by the anticonvulsant and antimanic agent valproic acid in vitro (Abstract). Annual meeting of Society for Neuroscience meeting. Miami Beach. November 1994

Cohen P, Alemany S, Hemmings BA, Resink TJ, Stralfors P, Tung HY (1988): Protein phosphatase-1 and protein phosphatase-2A from rabbit skeletal muscle. Methods Enzymol 159:390-408

Cohen P, Klumpp S, Schelling DL (1989): An improved procedure for identifying and quantitating protein phosphatases in mammalian tissues. FEBS Lett 250:596-600

Jackson S (1992): Regulating transcription factor activity by phosphorylation. Trends Cell Biol 2:104-108

Kalasapudi VD, Sheftel G, Divish MM, Papolos DF, Lachman HM (1990): Lithium augments fos protoonocogene expression in PC12 pheochromocytoma cells: implications for therapeutic action of lithium. Brain Res 521:47-54

Karin M, Smeal T (1992): Control of transcription factors by signal transduction pathways: The beginning of the end. TIBS 17:418-422

Korhauser JM, Nelson De, Mayo KE, Takahashi J (1992): regulation of jun-B messenger and AP-1 activity by light and a circadian clock. Science 255:1581-1584

Kuntz-Simon G, Orbert G (1995): Sodium valproate, an anticonvulsant drug, stimulates human cytomegalovirus replication. J Gen Virol 76:1409-1415

Leslie RA, Moorman JM, Grahame-Smith DG. (1993): Lithium enhances $5-\mathrm{HT}_{2 \mathrm{~A}}$ receptor-mediated $\mathrm{c}$-fos expression in rat cerebral cortex. Neuroreport 5:241-244

Löscher W. (1993): Effects of the antiepileptic drug valproate on metabolism and function of inhibitory and excitatory amino acids in the brain. Neurochemical Res 18:485-502

Manji HK, Lenox RH. (1994): Long-term action of lithium: A role for transcriptional and posttranscriptional factors regulated by protein kinase C. Synapse 16:11-28 
Manji HK, Potter WZ, Lenox RH (1995): Signal transduction pathways: molecular targets for lithium's actions. Archives of General Psychiatry 52:531-543

McElroy SL, Keck J, Pope J, Hudson II (1992): Valproate in the treatment of bipolar disorder: Literature review and clinical/guideline. J Clin Psychopharmacol 12:42S-52S

Post RM, Weiss SR, Chaung DM (1992): Mechanisms of action of anticonvulsants in affective disorders: Comparisons with lithium. J Clin Psychopharmacol 12:23S$35 \mathrm{~S}$

Promega protocols and applications guide. Madison, WI, Promega, 1991

Rogawski MA, Porter RJ (1990): Antiepileptic drugs: Pharmacological mechanisms and clinical efficacy with consideration of promising development stage compounds. Pharmacol Rev 42:223-286
Sheng M, Greenberg ME (1990): The regulation and function of $c$-fos and other immediate early genes in the nervous system. Neuron 4:477-485

Simon G, Moog C, Obert G (1994): Valproic acid reduces the intracellular level of glutathione and stimulates human immunodeficiency virus. Chem Biol Interact 91:111-121

Weiner ED, Kalasapudi VD, Papolos DF, Lachman HM (1991): Lithium augments pilocarpine-induced fos gene expression in rat brain. Brain Res 553:117-122

Williams MB, Jope RS (1994): Distinctive rat brain immediate early gene responses to seizures induced by lithium plus pilocarpine. Brain Res Mol Brain Res 25:80-89

Woodgett JR, Pulverer BJ, Nikolakaki E, Plyte S, Hughes K, Franklin CC, Kraft AS (1993): Regulation of jun/AP-1 oncoproteins by protein phosphorylation. Adv Second Messenger Phosphoprotein Res 28:261-269 